\title{
The Challenges of Using Online Authentic Materials in Reading Classroom for First-Year EFL Students
}

\author{
Rahma Dania*, Annisha Dyuli Adha \\ English Education Department, FKIP, Universitas Putra Indonesia YPTK Padang, Indonesia \\ *Corresponding author. Email: rahmadania.azed@gmail.com
}

\begin{abstract}
Authentic reading materials can be widely obtained from the internet nowadays. Exposing students with many real-life reading materials is necessary, but it cannot be denied that the use of such materials gives challenges to the students in comprehending them. This study attempted to explore the challenges faced by twenty-two EFL students in comprehending online authentic reading materials. Qualitative method was employed as the research design and it was conducted in a Reading Comprehension course for one semester. The participants of this research were 22 freshmen who majored in English Education department enrolled at a university in West Sumatera, Indonesia. In collecting the data, the researchers used observation, questionnaire and interview. The findings of the research showed that students encountered some difficulties in comprehending online authentic materials such as too many new words, English phrases, and English slangs. Moreover, the results also showed that students faced some challenges in reading the material when the length of the text is not appropriate for their level and the topic is too far from their interests.
\end{abstract}

Keywords: Online authentic materials, reading comprehension, reading skill

\section{INTRODUCTION}

In English Language Teaching, materials play significant role in helping students acquire the language skills (McGrath, 2013). Good materials provide the opportunity to learn plethora things in language classroom because materials expose the use of language inside and outside the classroom (Ahmed, 2017). This is become more critical in reading classroom. In reading class, students get written words as the main materials in acquiring this language skill. Those written words is important, not only in building students' knowledge but also in helping them obtaining language skills.

Several studies found that the use of authentic materials in language classroom is useful in providing the opportunities of introducing real use of language to the students. It is also helpful in assisting students acquiring their language abilities. Ahmed (2017) in his paper conclude that the use of authentic materials prepares learners to communicate with the real language. Similarly, Ekawati and Yusuf (2018) pointed out that using authentic materials support students to interact with the real world and discard the gap between real world and language classroom. Further, Ahmed (2017) claimed that authentic materials could also help the students to improve their communicative abilities such as linguistics, sociopragmatic, and discourse competencies.

Regarding teaching language skills, the research on the use of authentic materials have been conducted by some researchers in both receptive skills. In listening classroom, for example, Rahman and Suryati (2018) conducted a research about the suitability of using online authentic listening materials in listening classes and sound out that using appropriate listening authentic materials in pre, whilst, and post-listening activity offer "meaningful and purposeful uses for the target language". Moreover, Ekawati and Yusuf (2018) discovered that using authentic materials in listening classroom help the students to develop their listening ability. It can also build their motivation to learn and build their vocabulary mastery.

In teaching reading skill, Yasrida, Sutarsyah, and Sukirlan (2017) elaborated that reading authentic texts increase students' curiosity and their knowledge in general since these kinds of materials provide new insight for the students. Additionally, Islam (2018) reported that using real text in reading class effectively 
improved students' achievement in reading comprehension.

Furthermore, Albiladi (2019) who explored the benefits and challenges of using authentic materials in ESL reading classes discovered that not only generate the sense of reality and motivate the students, using authentic text can also increase students' cultural awareness. Moreover, in the end of their paper, these fellow researchers Albiladi, (2019), Apsari, (2014), Islam (2018), and Yasrida et al. (2017); suggest to the teacher to employ authentic materials in reading classes. Although the essential part of reading lesson is to learn reading strategies from the textbook (Dania, 2019), employing authentic text as the substitute of the text on that textbook will help students to understand the social context (Gebhard, 2017).

In this 4.0 era, authentic materials can be divided into printed authentic materials and online authentic materials. Consequently, teacher and students would be easier to find authentic materials, particularly those online authentic texts. Internet provides every kind of authentic materials that would possibly be beneficial for the teacher and the students to be used in English Language classroom, especially in Reading Comprehension course. Not only the kind of the texts, but internet also generates every potential theme and topic. It means that the teacher and the students choose several topics according to the theme or topic on the lesson plan.

Using online authentic materials in reading classroom means that the teacher has an important role in determining the appropriate online texts that will be used in reading activities. The teacher should discover sample texts that are suitable for the level of students' reading skill. Besides, the teacher should also make sure that the topic of the online text is relevant to the syllabus or the lesson plan in particular. That is why it is essential for the teacher to re-check the text before he/she brings it to the classroom. By doing this, the students will be able to enjoy their reading activity and comprehend the text effortlessly.

Even though the teacher has already checked the appropriateness of the text, there is no guarantee that the students will not find some difficulties in reading online authentic materials. Since the text is not intentionally written for the purpose of education, the students can face some challenges in doing their online authentic materials reading activity. For example, the vocabularies used in text might be not familiar yet to the students. Further, the writer of the text might use some proverbs that are also not familiar to the students. Thus, this study attempted to explore the challenges faced by twenty-two EFL students in comprehending online authentic reading materials.

\section{METHOD}

To understand the challenges faced by the students in reading online authentic materials, this study used descriptive qualitative method. This study was designed to concentrate on the kinds of challenges in reading online authentic materials for freshman ELT students. The study was conducted in reading comprehension 2 class in a private university in Padang, Indonesia. This course is an obligatory subject that has to be taken by English Education Department students in the second semester. This class was chosen as the site of the research since the researchers have good opportunities to conduct the research in this class and in this campus. Besides, on the lesson plan of this course, the students are expected to be able to read and comprehend the text critically. It means that, there are plenty of texts that can be used in this classroom. Therefore, doing a research of using online authentic texts which have tons of topics in this classroom can be considered as a proper study.

There were 22 students participated as the participants of the study. This quantity is the total number of all of the students in that class. The participants came from several regions in Indonesia which means they graduated from a wide range of learning background. In other words, the students are diverse in their language ability because some of them have been learning English since elementary school but some of them have been started their English learning since junior or senior high school. This is good to accomplish the purpose of this study which is to explore the challenges faced by the students in their reading online text activity.

In collecting the data, the method included in this study were questionnaire and interview. In term of questionnaire, it was given to the students in the end of the semester. Before the questionnaire was spread, the students were encouraged to read some authentic texts during teaching and learning process for several meetings in that semester. After that, in the end of the semester, the students filled in the questionnaire about the challenges they faced in reading online real text. Moreover, to confirm their answer and to collect more data, the interviews were conducted to 4 students.

\section{FINDINGS AND DISCUSSION}

Questionnaire is created in the form of 15 questions with different models of questions. The purpose of making different models of the questions is so that the researchers can collect the data that can describe the challenges faced by students in detail. By having this, the contents or answers on the questionnaire can be interpreted and described properly. The questions in the questionnaire were written in two languages, which are English and Indonesian. English is used so that the class atmosphere of the English Education Study Program 
matches the designed questionnaire. Meanwhile, Indonesian language is used so that participants can understand the exact meaning of each question written in the questionnaire. Hence, the students can enjoy the process of answering the questions and describing their challenges in their reading activity.

Questionnaires that have been designed are distributed to the students in Reading Comprehension 2 course who are chosen as research participants. There were 22 students in that Reading Comprehension 2 class who participated and answered the questions on the questionnaire. Questionnaire was distributed to participants on April 17, 2020. Participants were given sufficient time and chance to fill in the questionnaire so that they could answer each question properly and honestly, according to what they really wanted to convey.

One of the main questions on the questionnaire is the $11^{\text {th }}$ question. The question is written below.

11. What kind of challenges do you find when reading authentic text?

Too many difficult vocabularies

Too many English proverbs/ special phrases

The text is too long

The topic of the text is not interesting

In this question, the researchers asked the students to choose four kinds of problems/ challenges that are often faced by the readers when reading online English authentic texts. This is in accordance with the results of research conducted by Berardo (2006). In the results of his research, it was stated that authentic texts often contain some news vocabularies that did not match the level of students' vocabulary mastery or it had not been studied by the students yet. This kind of challenges will cause difficulties in comprehending their reading text. In order to accomplish this problem, Berardo (2006) provides a solution by advising teachers, lecturers or mentors to revise the language used in the authentic text. However, this will make the text no longer authentic.

The results of Berardo's research are in line with the results of research by Ekawati and Yusuf (2018) which states that the large number of new vocabularies in authentic text can make students feel difficult in understanding the content of the reading. In addition, complex language and the use of unfamiliar terms can put a burden on students in completing reading. This certainly will make students less motivated to read authentic texts.

For the decision of mentioning the length of the text as one of the challenges, the researchers considered that the text that was too long would reduce students' motivation to read and understand the text. In addition, a text that has too many vocabularies will make students spend too much time in understanding the contents of their reading. Meanwhile the reading text that must be comprehended in this course is not just one article. One meeting sometimes has two articles to be read by the students or participants. Furthermore, the topic becomes the other challenge that will make students constrained when reading authentic texts because the topic chosen sometimes does not necessarily suit the students' wishes. This kind of problem also cannot enhance their motivation to read more.

Students' answer or the data from this main question can be seen on the following graph in figure 1 below

11. What kind of challenges do you find when reading authentic text?

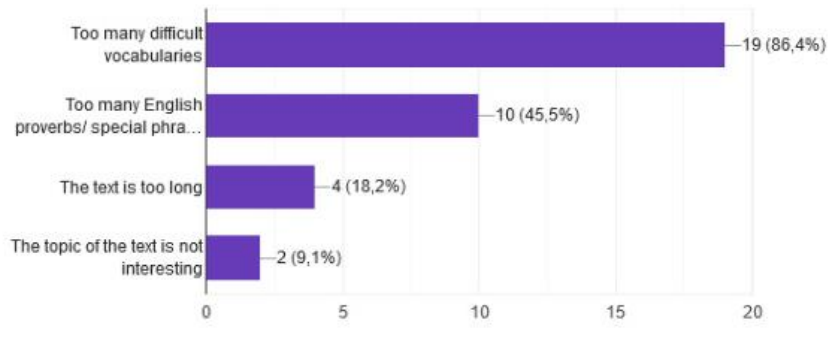

Figure 1 Students' answers

Based on the graph above, it can be concluded that the large number of difficult vocabularies in an authentic text is the biggest challenge faced by the students when doing reading activity in the form of online authentic reading text. This problem was chosen 19 times by 22 participants. It can be seen on the graphic that $86.4 \%$ of participants think that the biggest challenge in reading and understanding authentic text is the new vocabulary contained in authentic text. In addition, another challenge faced by many participants was the complexity of the language used in the reading and the terms written in the reading that were unfamiliar to the students' language skill or vocabulary mastery. In the graph, it can be seen that 10 out of 22 participants chose this option as the challenge that made it difficult for them to understand English reading in the form of Authentic Texts. In other words, $45.5 \%$ of the participants found it difficult to find special language terms and proverbs that they do not normally read in the texts they usually read.

In addition, in the graph, it can be seen that the length or number of sentences in a text and the topics written by the author in the selected text are not too burdensome or challenging for the students. From 22 participants, only 4 students thought that the length of a text could disturb their reading activity. It can be seen from the graphic that this kind of challenge shoes by 
$18.2 \%$ of the participants. Last but not the least, only 2 participants chose the topics of the text that did not match their interests as a challenge they had to face in building understanding of reading English text which was not taken from a special textbook for Reading Comprehension II class but was an authentic text.

As stated in the previous sub-title, methods, the data from the interview is used to gather more data. Hence, the interview was conducted to 4 students to get more detail information about the challenges that they found in reading online authentic materials. The data from the interview revealed some important points. First, enjoying reading activity by using guessing word meaning strategy can improve students' motivation to read online authentic materials. Meanwhile, when the text contains too many new vocabularies, the students would not be able to do this reading strategy easily. Second, finding the meaning of special vocabularies such as proverbs is not as easy as finding the meaning of a word. Therefore, when the text has some English proverbs that were not familiar to the students, they claimed that this problem made them difficult to comprehend the content of the text.

\section{CONCLUSION}

The results of this study showed that the most challenging part of reading online authentic materials is when the students found too many new vocabularies in the text. The result also revealed that students did not count the topic of the authentic materials as the challenge as long as they can understand the text easily.

Since the use of authentic materials in reading classroom still have some challenges for the students, the teacher/ lecturer is suggested to use online authentic materials in the classroom because it is very useful in helping the students acquiring language skills through the actual use of language, but it will be better when the teacher/lecturer revise some difficult vocabularies in the text. Meanwhile, for the future researcher, it will be better to conduct research on the use of online authentic materials for specific genre of the text.

\section{REFERENCES}

Ahmed, S. (2017). Authentic ELT materials in the language classroom: An overview. Journal of Applied Linguistics and Language Research, 4(2), 181-202.

Albiladi, W. S. (2019). Exploring the use of written authentic materials in ESL reading classes: Benefits and Challnges. English Language Teaching, 12(1), 67-77.

Apsari, Y. (2014). The use of authentic materials in teaching reading comprehension. ELTIN Journal, 2(2), 88-94.
Berardo, S. A. (2006). Thre use of authentic materials in the teaching of reading. The Reading Matrix, 6(2), 60-69.

Dania, R. (2020). Using online short stories to promote students, reading habit. In The Proceedings of the 7th International Conference on English Language and Teaching (ICOELT 2019) (pp.140.144).

Ekawati, D., \& Yusuf, F. N. (2018). Authentic Materials in Foestering EFl Students Listening Comprehension. Advances in Social Science, Education and Humanities Research, 254, 422-426.

Gebhard, J. G. (2017). Teaching English as a foreign or second language. Michigan: The University of Michigan Press.

Islam, S., \& Santoso, E. (2018). The effectiveness of using authentic texts in the teaching reading comprehension. ETERNAL, 4(2), 166-180.

McGrath, I. (2013). Teaching materials and the roles of EFL/ESL teachers: Practice and theory. New York: Bloomsbury Academic.

Rahman, H., \& Suryati, N. (2018). Authentic texts used by EFL vocational teachers in listening classes: Are they suitable with learners' needs? Jurnal Pendidikan, 3(5), 566-574.

Yasrida, N, Sutarsyah, C., \& Sukirlan, M. (2017) Using authentic materials in reading comprehension of students' low and high proficiency levels at SMAN 3 Bandar Lampung. UNILA Journal of English Teaching, 6(3). 